\title{
The Maintenance of Archive Collections in Times of Constricting Budgets: Some Alternative Approaches under Development on the UK
}

\author{
JONATHAN RHYS-LEWIS, ACR, CERTCONS \\ ICA Representative, United Kingdom \\ e-mail: jonathan.rhys-lewis@ntlworld.com
}

The Maintenance of Archive Collections in Times of Constricting Budgets: Some Alternative Appro-
aches under Development on the UK ABSTRACT

The paper will outline the key objectives for collections care and analyse the direct impacts on long-term preservation resulting from austerity measures. The particular focus will be on local government funded archive services that carry a statutory duty to preserve archive collections. What has been the effect on standards? The author considers how standards are developing and where he feels the emphasis has changed to reflect the change in funding. The availability and access to both government and private funding will also be assessed and how funding criteria are driving preservation decisions. What options are there for improving storage and managing collections? How can archive services reduce and manage risk when the status of archive services is constantly under review and resources are scarce? The need for robust collecting and preservation policies is becoming a key strand of the response from both archivists and conservator-restorers. Additionally, this paper will investigate the increased challenges of promoting preservation in the absence of experienced, professional staff, and how the use of volunteers is shaping policy. The presentation will then assess the capacity and efficacy of the commercial sector in assisting with the maintenance and development of collections. The author hopes that by outlining current approaches in the UK, other countries will feel more confident to consider and explore similar models.

Key words: long-term preservation, Archives, United Kingdom, founding, standards, risk assessment, volunteers, commercial sector

La gestione delle collezioni archivistiche in tempi di bilanci ristretti: alcuni approcci alternativi in via di sviluppo nel Regno Unito

\section{SINTESI}

L'articolo delinea gli obiettivi chiave per la cura delle collezioni ed analizza l'impatto diretto sulla conservazione a lungo termine risultanti dalle misure di austerità. Si focalizza in particolare sui servizi archivistici finanziati a livello locale che comportano un dovere statutario nella conservazione delle collezioni archivistiche. Qual è stato l'effetto sugli standard? L'autore prende in considerazione come gli standard si siano sviluppati e dove egli sente sia cambiato l'interesse a riflettere sul cambiamento nel finanziamento. Saranno inoltre stimate disponibilità e l'accesso ai fondi sia governativi che privati, e come i criteri di finanziamento guidino le decisioni sulla conservazione. Che opzioni ci sono per migliorare la conservazione e la gestione delle collezioni? Come possono i servizi archivistici ridurre e gestire il rischio quando il livello di tali servizi è costantemente sotto revisione e le risorse sono scarse? La necessità di solide politiche di acquisizione e conservazione sta diventando un fattore chiave della risposta sia da parte degli archivisti che dei conservatori-restauratori. Inoltre, il presente articolo investiga le sfide crescenti per la promozione della conservazione in assenza di personale esperto e professionale, e l'uso del volontariato come politica di formazione. La presentazione valuterà quindi la capacità e l'efficacia del settore commerciale nell'assistere la gestione e lo sviluppo delle collezioni. L'autore spera che delineando gli approcci attuali nel Regno Unito altri Paesi prendano confidenza e considerino ed esplorino modelli similari.

Parole chiave: preservazione a lungo termine, archivi, Regno Unito, fondazione, norme, valutazione del rischio, volontari, settore commerciale 
Vzdrževanje arhivskih fondov in zbirk v času nizkega proračuna: razvoj nekaterih alternativnih pristopov v Veliki Britaniji

\section{IZVLE ČEK}

V prispevku bodo predstavljeni ključni cilji varovanja zbirk in analiza neposrednih vplivov na dolgoročno hrambo, ki so posledica varčevalnih ukrepov. Poseben poudarek bo na arhivskih službah, ki jih financira lokalna uprava in ki opravljajo zakonsko dolžnost hrambe arhivskih zbirk. Kakšen je bil učinek na standarde? Avtor v prispevku razmišlja o razvoju standardov in o tem, kje je prišlo do sprememb, ki so odraz spremembe v financiranju. Prav tako bo predstavljena razpoložljivost in dostop do vladnih, kot tudi do zasebnih sredstev, ter kako merila za financiranje vplivajo na odločitve glede hrambe. Kakšne možnosti obstajajo za izboljšanje hrambe in upravljanja zbirke? Kako lahko arhivske službe zmanjšujejo in obvladujejo tveganja, če so arhivi nenehno pod drobnogledom, finančni viri pa nezadostni? Potreba po robustni zbiralni in ohranjevalni politiki postaja ključno stališče odgovora tako arhivistov, kot tudi konservatorjev in restavratorjev. Prav tako bo prispevek predstavil večje izzive pri ohranjanju zbirk, ki so posledica pomanjkanja izkušenega in strokovnega osebja in kako v hrambo vključiti prostovoljce. $\mathrm{V}$ prispevku bo predstavljena tudi učinkovitost gospodarskega sektorja pri pomoči glede vzdrževanja in razvoja zbirk. Avtor prispevka želi z opisom pristopov k vprašanjem hrambe v Veliki Britaniji vzpodbuditi tudi druge države, da bi pričeli razmišljati in raziskovati podobne modele.

Ključne besede: dolgoročna hramba, arhivi, Velika Britanija, financiranje, varčevalni ukrepi, standardi, obvladovanje tveganj, prostovoljci, gospodarski sektor

The focus of this paper is to assess the impact of consistently reducing financial resources for the maintenance of moveable heritage collections in the UK. Further discussion is presented on the effect these pressures have had on the maintenance of standards and also presents a quick overview on the developing production of European standards for collections care activities. The discussion then moves on to assess how the storage and management of collections has changed from the central provision of services to a more flexible approach to outsourcing elements of professional care and the use of commercial providers for storage. Finally, there is an overview of the effect these changes are having on staffing levels and the ever-growing use of volunteers.

As an initial starting point it is pertinent to consider what are the key objectives for collection care? In general, the approach is to identify all of the main risks to collections throughout the process of the management of those collections. So, as a useful catch-all, it is useful to consider all the areas where collections are at risk, and so where collections care has a significant role to play. Fortunately the Canadian Museum of Nature, through the significant inputs of Stefan Michalski and Rob Waller, have done much of this work, and have defined the Ten Agents of Deterioration as follows:

- Physical Forces

- Thieves and Vandals

- Fire

- Water

- Pests

- Pollutants

- Light and Ultraviolet and infrared radiation

- Incorrect Temperature

- Incorrect Relative Humidity

- Dissociation (sometimes also called custodial neglect) (see Waller, Cato, 2016).

These should all be familiar to those working with heritage collections, but maybe the word "dissociation" is less clear. The definition's key point is that "Dissociation results from the natural tendency for ordered systems to fall part over time". Of course this could also be linked to collections - organic materials decay, and there is no overall solution to retard this natural, chemical degradation; however, we can do some things that will delay this process and so extend the life time of the carriers of the information, so giving the custodians, more time to secure these materials and, most importantly, to provide access to the information.

Of course, this list is not exhaustive but serves to illustrate the variety and range of activities that 
have an impact on the condition of heritage collections; however, this paper focuses on archival collections. In the UK, local government archives have a statutory duty to preserve their collections, and this is the single most important factor to ensure long-term preservation. The focus therefore is to address risk wherever it presents itself, and specifically where it directly impacts on providing access to the information in collections. The definition of risk, as it associated with collections, could be:

$$
\text { Risk }=\text { Probability of loss (of value) }+ \text { impact }
$$

It is important to be clear that this may be a loss of collections, a loss of value (both financial and historical) or loss of status for the institution should collections be damaged or destroyed whilst in their care.

This risk needs to be removed, but this is not always possible. We can mitigate the risk - reduce the effects; we can assess if there are other reasons or agencies that are causing this risk - this may address the problem or at best control the effects; or, ultimately, we may have to accept the risk - at least until something can be done about it.

So, all these points are fine and the theory works well, but unfortunately many of these care elements cost money and that money is becoming harder not only to find but also to justify. Consequently organisations have to think about ways to reduce costs and expenditure. Archives are very exposed, as in general the service is connecting with, proportionally, quite a small part of the population, and yet archive services have some significant costs - primarily the expense of maintaining storage environments. As a profession we are very clear and have a detailed understanding of the deterioration rates of our collection materials - particularly paper and leather. Although the oncoming issues presented by digital data are on a similar but less physical level, the major challenges of preserving digital information, storing that information and providing access to that information is a separate subject altogether.

The cost of maintaining an archive building, and most especially the repository areas is becoming increasingly difficult to justify. The requirement for the building and the storage areas to meet specific standards puts a significant strain on any organisation that has to make tough financial decisions and needs to impose cuts. The main issue is the control and maintenance of the internal storage conditions, but these may be easily affected by the external climatic conditions, especially in buildings that have not been purpose-built for archives (few are). Much work has been done to identify the most appropriate levels of both temperature and Relative Humidity required for archival material. However, these ranges have also been further refined to cater for the needs of more sensitive formats such as photographic material, film and modern media, thus presenting more challenges. For most institutions the only way to ensure that the environmental conditions remain at an optimum, with little opportunity for fluctuations, is to invest in mechanical means.

The installation of heating and ventilation systems, and more specifically air-conditioning equipment has been the single most effective step, and the highest investment. Once the plant is in place, there is direct control over the air supply (and how often that supply is renewed), the filtration of that air supply (particularly relevant in areas of high pollution), the conditioning of the air (how much or how little moisture it contains), and the temperature of this air supply. To enable the maintenance of these conditions requires the equipment to be running 24/7 and this is a costly undertaking. In addition this equipment also has other, external environmental impacts, producing quantities of $\mathrm{CO} 2$, whilst eating up electricity. Many organisations also have targets to reduce the carbon footprint and so an archive building can be seen to present significant weaknesses in attaining this objective.

So, how might this problem be addressed? One option is to turn off the equipment, but this may result in the conditions quickly becoming toxic for the collections - high humidity levels and higher temperatures resulting in moulds; drier conditions and warmer temperatures resulting in sensitive formats becoming desiccated, deforming or encouraging chemical impacts. These impacts may result in damage to photographic images and the acid deterioration of leather book coverings causing "red rot", thus increasing dust levels. Dust has a range of impacts; it is unsightly; it affects some people with respiratory problems; it collects and provides a foodstuff for insects and moulds. Dust in archives can of course be addressed by a good housekeeping programme but it remains the fact that poor environmental conditions are contributing to this problem. 
Some organisations in the UK have been experimenting with turning off air-conditioning systems to see how long it takes for environmental levels to be affected and/or how easily the internal conditions are influenced by external climatic and seasonal changes. This data has enabled some archives to realise that by improving insulation - and this may be just blocking up windows - or using the equipment at certain points in the seasonal cycles, that little negative impact occurs and so significant savings can be made. There are examples in the UK where air-conditioning systems are turned off overnight, or over weekends, and in some cases are left off completely. In most cases there is a back-up of humidification or dehumidification capability.

So, it is a developing are of research and needs to be carefully planned - this presents an opportunity a considered approach to the management and control of environmental conditions. This requires investment in specialised equipment to record both temperature and Relative Humidity and this can be achieved by using one (or all) of the following:

- Thermometers

- Hygrometers

- Thermohygrographs

- Digital Thermohygrographs

- Recording Dataloggers

- Radio telemetric systems

Many archives feel that monitoring a space that they cannot control or change is a waste of time. This is not true. Monitoring environmental conditions is a key element of ensuring collection care. Without the data archivists and conservators cannot effectively argue for more resources, lobby for new buildings or prove the risk to the collections of sub-standard storage spaces. This would seem obvious, but in a survey of archive and library institutions in the UK (carried out in 2012) under 40\% of respondents were undertaking environmental monitoring. So, all this attention on maintaining collections carries a price and it is by the use of standards that we can set the exemplars and so convince managers, and accountants, of the need to maintain collections, to preserve them, so that the information they contain is accessible to future generations.

The use of both national and international standards has been a vital component in enabling collection care. In the UK the use of established national standards for archival collections has resulted in a significant period of building - both new builds and conversions - as old building stock has become unfit for purpose and presents a very real risk to both ongoing collection care and the maintenance of collections into perpetuity. The key standards in the UK have been:

British Standards Institution (BSI), PD 5454: 2012, Guide for the storage and exhibition of archival documents

British Standards Institution, PAS 198: 2012, Specification for managing environmental conditions for cultural collections,

These two standards resulted from the review of a previous standard (BS 5454:2000) and the production of two from one (as above) illustrates how much more defined standards have become, and this further accentuates our need for them. However, the standards landscape has now changed with the publication of the new European standard:

Conservation of Cultural Heritage - Specifications for the location, construction or modification of buildings or rooms intended for the storage or use of heritage collections.

This standard is the result of two years of work by a committed group of European specialists to build on the UK standard, but also to define more accurately the core standard requirements, harmonised across Europe. A European standard overrides a national standard and takes precedence, so the two UK standards are now withdrawn. One of the key influencers for change originated from a meeting of national museum directors who were finding that the previous environmental storage levels, especially when applied to loans to other organisations, were becoming too costly to maintain, both financially and environmentally. The group asked the conservation community to revisit the previous, rather inflexible tolerance margins for the range of materials held in heritage institutions. The UK standard PAS 198 was the first result of those labours, and now, a key focus of the new European standard is sustainability and energy efficiency. 
One of the key ways in which an organisation can improve the long-term maintenance and care of collections is to build a new structure that will enable the Whole Life Costing of the building to influence the decision-making. An important focus of this approach is the encouragement to develop ways to ensure stable environmental storage conditions without the recourse to mechanical means. A passive climate building design is clearly the future for archive buildings, but at this time, little research in the UK has been carried out and most new builds, whilst having some sustainable elements, do not fully address the sustainability agenda. This is probably due to range of issues including lack of suitable research data, potential costs and a fear of change. Whilst there are some interesting and developing approaches, including a version of the German Passivhaus system for an archive building (for more see Passivhaus, 2016), these are big issues and change is always slow.

Most organisations have concerns about storage conditions and one of the ways to address this is to invest in a new building. Clearly cost will be a major barrier for most organisations especially in times of austerity when all levels of government are required to make huge, and often crippling savings. So, in the UK, many archives are looking for funding elsewhere, and externally to the organisation. A key funding body in the UK is the Heritage Lottery Fund (2016), whose role is to distribute the money raised by National Lottery players to extend and protect heritage. The HLF is the largest dedicated funder of heritage in the UK and this year alone has $£ 430$ million to invest in appropriate projects - although not all on archives. The HLF has been a key funder of new archive buildings and has a range of different grant programmes providing funding from $£ 3,000$ to over $£ 5$ million.

However, the HLF does not give grants without significant work having taken place on the application, and each case is carefully assessed to ensure that public money is appropriately spent and that there is a very real benefit and engagement with the public. Alongside the HLF are other grant funding bodies in the UK, some private, who are equally committed to ensuring value for money, and this will be reflected in the criteria underpinning the different grants. These criteria may require specific emphases and requirements, which in turn will influence, and sometimes dictate, the outcome of the project. So, archives need to think creatively when compiling an application, and this will necessarily widen the focus away from the direct impact of collection care.

Another new initiative in the UK is Archives Accreditation, which is owned and managed by the National Archives (see Archive Service Accreditation, 2016). The purpose of the scheme is to "enable archive services to review and develop their policies, plans and procedures against a UK wide standard which has been developed by the archives sector, identifying strengths of the archive service and providing a framework to improve areas of weakness." In this way, archive services are being encouraged to think more strategically about how they manage the collections, and this has an effect on collection care. A successful application results in the award of accredited status; one of the benefits is to "raise the profile of archive services by building confidence and credibility both within the parent organisations and externally, through increased awareness and understanding." The award is also seen as external recognition of a particular service and so this inevitably will have an impact on the organisations' capability and capacity for compiling funding applications.

Currently, in the UK, archive services are getting squeezed between the needs of the collections and the constricting resources required to maintain them. For collection care, the need to reduce budgets and create savings has two main impacts; firstly, it is becoming increasingly difficult to maintain storage facilities to appropriate standards (often services have a number of storage sites in different locations), and secondly, it is, in the eyes of the accountants, becoming a luxury to sustain specialist collections staff - this could include collections care, conservation and repository staff.

The one key strength, but also a point of stress (and sometimes conflict), is that local government archives are statutory and the organisation's ability to preserve and provide access to public records is strictly monitored. There are estimated to be just over 1,000 linear $\mathrm{km}$ of records in UK local authority archive services and so it is vital that the long-term preservation of these collections is maintained. The Places of Deposit scheme is managed and monitored by the National Archives, and should a particular service fail in this objective then, in theory, the collections would be transferred to the National Archives. This would be on a temporary basis until the issues were resolved; however, this act would have impacts on other depositors, the status of the archives in the locale and on professional profile. 
In the UK, there has been a huge increase in the number of commercial storage companies - one can be found in most major towns - providing secure space for anyone to store their belongings. Whilst the majority of use is for domestic clutter, furniture, or a stop-gap during a house move, some of the companies are becoming aware of the specialised needs of archives - and consequently a new market. Many commercial storage companies in the UK have been storing semi-current records for local authorities (and others); these services include retrieval/ replacement, transport and destruction. Some storage companies have made the significant investment to bring facilities up to the requirements of PD 5454: 2012, and will now be focusing on the new European standard. This has resulted in a competitive and fairly vibrant marketplace for the off-site storage of heritage, and in particular, archival collections.

The availability of commercial storage has a two-fold effect; it reduces the amount of material stored at the archive's main site and so creates extra space and perhaps, most importantly, this arrangement results in the creation of a new budget head that is easier to maintain within local authority finances. Additionally, much of the responsibility for the day-to-day maintenance of the storage now falls onto the commercial provider. Interestingly, this seems to be a fairly unique UK arrangement at the moment. A recent survey by the International Council on Archives focusing on archive building provision, asked the question - "Is commercial storage used for low usage collections?" The survey included respondents from all over the world, from 56 countries. Only $12.35 \%$ used a commercial provider (and these could have been UK responses); on the other hand, $87.65 \%$ did not. So, this is clearly not an issue for the majority of other countries, possibly reflecting that the commercial sector is undeveloped, that there is an unwillingness to pass over the responsibility for collections material, there may be concerns over security, or over operational issues in providing access to original material stored off-site.

It would seem therefore that this commercial sector in the UK is not reflected elsewhere and so UK companies have a new marketplace to develop in Europe. However, it may also be that other countries national standards and accounting protocols preclude this kind of solution. These concerns are of course important, and it is absolutely vital that an organisation wishing to store collections offsite compiles a robust specification to ensure that standards are met, that appropriate insurance is in place and that penalties apply for non-compliance.

To explore the services being offered in the UK, it is necessary to look in more detail at two UK companies - Deepstore and the Collaborative Storage Scheme (run by the National Conservation Service).

Deepstore, based in the English county of Cheshire is a working salt mine - the storage facility is $150 \mathrm{~m}$ below the surface (for more see Deepstore, 2016). The current workings are a long way from the storage facility, which rather ingeniously fills in the excavated caverns with storage units. Being so deep underground results in "consistent temperature and humidity levels" and is also free from the dangers of the surface including ultraviolet light, wind or flooding. The facility currently houses collections from a variety of heritage institutions, and most importantly the National Archives. Deepstore provides temperature and Relative Humidity controlled vaults, which also include advanced filtration systems for the airborne salts in the mine's general atmosphere.

The Collaborative Storage Scheme is a unique service that brings together a group of heritage institutions, all who require high quality storage at a reduced cost (for more see The Collaborative Storage Scheme, 2015). This is made possible by an innovative arrangement with the UK's second largest storage business, Restore. This collaborative scheme has enabled the conversion of existing specialised aircraft hangers on a previous US air force base (within an extra secure enclosure on the site) at Upper Heyford, in Oxfordshire. Whilst Restore provide the storage spaces, the National Conservation Service (2015) acts for each of the heritage organisations, and NCS professional conservation staff monitor the environmental conditions of the store and advise on collection needs and transfer of collections to, and from, the site. In addition, NCS provides, to a wide range of members (not all who use the storage site), advice on management, practice and training in collection care - this can include surveys, remedial conservation and digitisation projects - all provided within a not-for-profit membership scheme (with a range of subscription levels).

Storage is now only one element of the UK's commercial services. There is a large and well- 
managed private conservation sector, and an effective professional body, The Institute of Conservation, which represents nearly 3,000 individuals and organisations (see The Institute of Conservation, 2016) . Icon also manages the Professional Accreditation of Conservator-Restorers (PACR) scheme and this in turn links with the Conservation Register, which is the portal for sourcing professionally qualified conservators in the UK and Ireland. There are also providers of commercial disaster planning support, which includes freezer trucks, freeze-drying and training, and a number of institutions are investing in boxmaking machines and offering a commercial service to other institutions that want to reduce the cost of buying in good quality archival packaging.

So, finally this leads to how to extend the capacity of institution's to carry out collections care projects. A developing are and one that continues to expand, is the use of volunteers (for more see Volunteering in Collections Care, 2011). The Archives and Records Association in the UK has acknowledged that whilst in principle, the use of volunteers can undermine the need for professional staff, reducing budgets mean that there is little room for manoeuvre. The research identified that the largest number of volunteers was hosted by local authority services and that $89 \%$ of organisations have a volunteer policy. The majority (93\%) carry out records description \& cataloguing, whilst $85 \%$ are involved in conservation and preservation activities; scanning and digitisation projects account for $50 \%$. The collection care activities that volunteers can undertake is also quite wide:

- re-packaging

- numbering and stamping

- surveying

- surface cleaning books and documents

- flattening \& re-folding documents

- sticking in loose pages

- paper repair

- re-binding books

- repair of books

- box making

Whilst all the risks of using volunteers are clear, there is an additional benefit to organisations by demonstrating the value of volunteering in funding applications.

\section{Conclusion}

This paper has presented a range of options for consideration, and has set these within the context of current changes and activities within the UK. These models could be repeated elsewhere, but there are pitfalls, and any commercial sector needs a sufficient pool of users for it to be economically viable. It also starts a significant change in how others view the status and viability of archive services and this in itself can be a risk. However, there are many positives within these models, and different kinds of options (and financial pressures) will create different kinds of services; maybe this is what will influence the archival landscape over the next 10 years and into the future? It is of course important to be flexible and to allow elements of compromise, but it is vital to underline and highlight the key principles of collection care. Consequently, the profession needs to be open and creative to find new ways to achieve the objective of long-term preservation, which enables access to information. Funders need to appreciate and understand that maintaining collections is the objective and accept that the ongoing funding of collections care for the benefit of future generations is not an option but a priority.

\section{References}

Archives Accreditation (2016). Available at: http://www.nationalarchives.gov.uk/archives-sector/archive-serviceaccreditation.htm (accessed May 2016).

Collaborative Storage Scheme (2015). Available at: http://www.ncs.org.uk/collaborativestorage.php (accessed May 2016).

Conservation of Cultural Heritage - Specifications for the location, construction or modification of buildings or rooms intended for the storage or use of heritage collections. 
Jonathan RHYS-LEWIS: The Maintenance of Archive Collections in Times of Constricting Budgets: Some Alternative Approaches under Development on the UK, 105-112

Deepstore (2016). Available at: http://www.deepstore.com (accessed May 2016).

Heritage Lottery Fund (2016). Available at: https://www.hlf.org.uk/about-us (accessed May 2016).

National Conservation Service (2015). Available at: http://www.ncs.org.uk/ourservices.php (accessed May 2016).

PAS 198: 2012, Specification for managing environmental conditions for cultural collections. British Standards Institution (BSI).

Passivhaus (2016). Available at: http://www.passivhaus.org.uk (accessed May 2016).

PD 5454: 2012, Guide for the storage and exhibition of archival documents. British Standards Institution (BSI).

The Institute of Conservation (2016). Available at: http://icon.org.uk/about-us (accessed May 2016).

Volunteering in Collections Care (2011). Available at : http://www.archives.org.uk/images/documents/VOLUNTEERING_in_COLLECTIONS_CARE_-_GUIDE-1.pdf (accessed May 2016).

Waller, R. R., Cato P. S. (2016). Agent of Deterioration: Dissociation. Available at: http://canada.pch.gc.ca/ eng/1444924574622 (accessed May 2016).

Typology: 1.02 Review Article

Submitting date: 26.01 .2016

Acceptance date: 20.02 .2016 